\title{
INTEGRASI KURIKULUM PESANTREN DAN MADRASAH PADA PONDOK PESANTREN MANBA'UL 'ULUM SINDANGMEKAR DUKUPUNTANG CIREBON
}

\author{
Siti Maryam Munjiat \\ Fakultas Ilmu Tarbiyah dan Keguruan \\ Institut Agama Islam Negeri Syekh Nurjati Cirebon \\ Email: Sitimaryammunjiat@gmail.com
}

\begin{abstract}
Turbulence of education in Indonesia has been experienced since a period of Netherland Colonial, both of general or religion. In the earlier Islamic education institute in this case is Pesantren (Islamic Boarding School) representing eldest institute in Indonesia with traditional characteristic have felt direct collision with Netherland Colonial, which according to their doctorine of Pesantren resistance for them. Leaving from this, then there is polarization between Pesantren (Islamic Boarding School) and school as a product of Netherland that born general school triggering dichotomies. But, there any dissimiliar factor that continue the existence of the dichotomies without confusing the value of education and optimal achievement?

The aim of this research to reply and explain about factors of the happening the integration of curriculum. Others also, research intended to lift the spirit of education institute base on religion, that is Pesantren an Madrasah (representing gene from pesantren with systematic curriculum) in integrating both of curriculum both. One all important matter again in this research is eliminate boundary and apart between general science and theology with existence integrate curriculum as have done all his predecessor, that is Pesantren Gontor Ponorogo, Pesantren Darul Arqom Garut, Pesantren al-Amin Madura with different manner and pattern. Existing also in Pesantren manba'ul 'Ulum Cirebon represent object of research that is about the integration.

The integration of curriculum at education institute base on religion (Pesantren and Madrasah) have successful result such as those which reached for by big name of Pesantren Gontor Ponorogo and then followed by other Pesantren and proven from exponent, output from each Pesantren when have acted in society.
\end{abstract}


Method of this research is used field research-field research that having the character of analytic descriptive that is in order to object the research can be explained and formulated and also analyse the happening integration of curriculum.

The result obtained in this research is the manifestation from integration curriculum Pesantren and Madrasah implemented at Pesantren Manba'ul 'Ulum Sindangmekar Dukupuntang Cirebon is not quit of the general and religion science, epoch demand, study continuation of all Santri (student of Pesantren), legitimating from society and government. All of them represent mutual framed in social-culture.

Keywords: Curriculum Integration, Madrasah, and Pesantren 


\section{A. Pendahuluan}

Pesantren merupakan lembaga pendidikan khas Indonesia, sebuah lembaga yang mempertahankan pengajaran bahasa Arab, tauhid, tafsir, hadits, akhlak tasawuf, dan kitabkitab mu'tabaroh. Memegang teguh diktum al-muhafadhah 'ala al-qodim al-sholeh wa alakhdzu bi al-jadid al-ashlah (melestarikan nilai-nilai lama yang baik dan mengambil nilainilai baru yang lebih baik). Semboyan ini memberikan ruang bagi pesantren untuk selalu dinamis dalam menyikapi perubahan di dunia pendidikan.

Perkembangan pesantren tersebut terlihat ketika pesantren berhadapan dengan sekolah-sekolah yang didirikan oleh Belanda pada masa kolonial juga munculnya lembaga pendidikan Islam modern yang dipelopori oleh kaum reformis pada abad ke-20 di Indonesia. ${ }^{1}$ Hal itu yang kemudian menjadi sebuah tantangan yang memicu pesantren untuk mendirikan madrasah sekaligus mengakomodasi tantangan tersebut. Dengan madrasah, tarik menarik antara keinginan pesantren untuk mempertahankan identitas dan cirri khas di satu sisi, dengan keharusan mengakomodasi perubahan di sisi lain, bisa diatasi. Pesantren yang memiliki madrasah bisa lebih fleksibel, dan bisa bertahan lebih baik, daripada pesantren yang tidak memiliki madrasah. Dengan pesantren, tradisi kiai, kitab kuning dan tafaqqug fiddin bisa dipertahankan; dengan madrasah, kebijakan-kebijakan pemerintah -terutama menyangkut kurikulum- dan tuntutan masyarakat dan untuk mempersiapkan anak-anak mereka yang tahu agama dan ilmu pengetahuan umum sekaligus bisa diakomodasi. Maka atas dasar rangsangan tersebut lahirlah madrasah dari rahim pesantren.

Madrasah yang berusaha melakukan pembaharuan menghadapi kenyataan bahwa out put dari madrasah serba tanggung, pengetahuan agamanya tidak mendalam sedangkan pengetahuan umumnya juga rendah. Hal tersebut diakibatkan adanya pengurangan proporsi pendidikan agama dari $60 \%$ mata pelajaran berbasis agama dan $40 \%$ mata pelajaran berbasis umum menjadi 30\% MP agama dan 70\% MP umum, sebagai konsekuensi masuknya madrasah dalam sistem pendidikan nasional. ${ }^{2}$

\footnotetext{
${ }^{1}$ Azumardy Azra, Pendidikan Islam: Tradisi dan Modernisasi Menuju Milenium Baru (Jakarta: Logos, 1999),
} 99.

${ }^{2}$ Dawam Rahardjo, Madrasah Sebagai The Centre Of excellence, dalam Ismail SM, Dinamika Pesantren dan Madrasah (Yogyakarta: Pustaka Pelajar 2002), 228. 
Fenomena di atas telah menimbulkan upaya-upaya dalam memaksimalkan proporsi pendidikan agama dan umum dalam sebuah kurikulum yang integratif. Usaha tersebut telah dicoba dan dilaksanakan di berbagai pesantren yang kemudian sebagai manifestasi dari konsekuensi tersebut adalah diadakannya lembaga pendidikan dengan sistem madrasah. Salah satunya adalah di sebuah yayasan yang bergerak dalam bidang pendidikan Islam berupa pesantren dan juga madrasah bahkan sekolah ${ }^{3}$ yang berada di wilayah kabupaten Cirebon. Lebih tepatnya berlokasi di desa Sindangmekar Kecamatan Dukupuntang Kabupaten Cirebon. Lembaga pendidikan ini selanjutnya dinamakan Pondok Pesantren Manba'ul 'Ulum.

Pada awal pertumbuhan dan perkembangannya sejak didirikan pada tahun 1983 pesantren ini, merupakan "pondok alumni" al-Amin Madura yang berusaha menerapkan kurikulum al-Amin apa adanya. Namun tuntutan dari perkembangan dunia pendidikan menimbulkan inisiatif pendiri pesantren untuk menerapkan kurikulum yang lebih integratif dengan menggabungkan kurikulum sekolah dengan kurikulum pesantren yang merupakan inovasi baru dan tidak berkembang dibalik bayang-bayang kebesaran nama pondok al-Amin. Inisiatif tersebut timbul dengan didasari pemikiran bahwa perlunya sebuah model lembaga pendidikan semacam pesantren yang memiliki kurikulum yang baik untuk menjawab ketimpangan kemampuan out put sebagaimana dipaparkan di atas. Maka diambillah keputusan untuk mendirikan lembaga-lembaga pendidikan di bawah pengawasan kyai sebagai sebuah dinamika di pesantren ini.

Lembaga pendidikan ini (pendiri dan masyarakat menyebut lembaga ini pesantren atau pondok pesantren) memiliki tujuh lembaga pendidikan, yaitu RA Islamiyah, Madrasah Diniyah Awaliyah Islamiyah, SMP Sindangjawa, SMK Manba'ul 'Ulum, Madrasah Aliyah Manba'ul 'Ulum, Kelompok Bimbingan Ibadah Haji, dan Majelis Ta'lim. Tiap-tiap lembaga pendidikan dipimpin oleh seorang kepala sekolah yang memiliki tanggung jawab terhadap terlaksananya kurikulum umum, sedang kurikulum pesantren (agama) di bawah tanggungjawab TMI (Tarbiyatu al-Mu'alimin al-Islamiyah) dalam hal ini qismu al-Ta'lim (bagian pengajaran) yang dilaksanakan dengan kooperatif dan kolaboratif.

\footnotetext{
${ }^{3}$ Penyebutan nama madrasah adalah sebagai wakil dari lembaga pendidikan formal yang berbasis agama sekolah agama Islam modern dengan sistem klasikal dan pengajaran di dalamnya telah tersusun dalam kurikulum. Sedang penamaan sekolah merupakan lembaga pendidikan yang berbasis umum yang asal muasalnya adalah garapan colonial Belanda. Lihat pada Abdul Rachman Shaleh, Madrasah dan Pendidikan Anak Bangsa (Jakarta: RajaGrafindo Persada, 2004), 12-13.
} 
Pondok pesantren Manba'ul 'Ulum memiliki semboyan: "Berilmu amaliyah, beramal ilmiyah, berakhlaq karimah, dan berwawasan teknologi. Dalam penelitian sementara memang didapati mata pelajaran umum dan agama yang diajarkan di pesantren ini, dengan pemadatan materi dan penambahan alokasi waktu mata pelajaran. Juga ditemui evaluasi pendidikan berupa ujian lisan dan tertulis untuk mata pelajaran pesantren dan ujian tertulis untuk pelajaran umum yang terkadang untuk evaluasi ini saja membutuhkan waktu sekitar setengah bulan.

Berangkat dari kebijakan pondok untuk mengadakan terobosan-terobosan dalam mensikapi dinamisasi pendidikan tersebut, maka penyusun akan mengadakan penelitian tentang Integrasi Kurikulum di Pondok Pesantren Manba'ul 'Ulum, sekaligus juga mengangkat persoalan yang ada, dan diruangkan dalam bentuk tesis.

Dari pemaparan latar belakang masalah di atas, maka untuk memperjelas dan mempertegas penelitian ini, ada tiga poin yang dapat dijadikan sebagai pokok masalah:

1. Apakah faktor-faktor yang menimbulkan perlunya integrasi kurikulum di Pondok Pesantren Manba'ul 'Ulum?

2. Bagaimanakan metode integrasi kurikulum di Pondok Pesantren Manba'ul 'Ulum?

3. Apakah integrasi kurikulum di Pondok Pesantren Manba'ul 'Ulum dapat dijadikan alternatif pengembangan kurikulum pesantren?

\section{B. Metodologi Penelitian}

\section{Jenis Penelitian}

Jenis penelitian ini adalah penelitian lapangan (Field Research) yaitu penelitian yang dilakukan untuk memperjelas kesesuaian antara teori dan praktek dengan menggunakan data primer. ${ }^{4}$ Dalam hal ini integrasi kurkulum di Pondok Pesantren Manba'ul 'Ulum Desa Sindangmekar Kecamatan Dukupuntang Kabupaten Cirebon, didiskripsikan serta dianalisis sehingga dapat menjawab persoalan yang telah dirumuskan dalam pokok masalah.

\section{Sifat Penelitian}

\footnotetext{
${ }^{4}$ Sujono Sukanto, Pengantar Penelitian Hukum, Cet. III, (Jakarta: UII Press, 1986), 51.
} 
Penelitian ini bersifat deskriptif analitik. Deskriptif adalah penelitian yang dapat menghasilkan gambaran dengan menguraikan fakta-fakta. ${ }^{5}$ Dalam hal ini penyusun memaparkan tentang terjadinya integrasi pendidikan di Pondok Pesantren Manba'ul 'Ulum, sedangkan analitik bersifat mengembangkan fakta-fakta integrasi kurikulum tersebut secara kondisional dan determinan-determinan dari suatu peristiwa. ${ }^{6}$

\section{Pendekatan Penelitian}

a. Pendekatan histories, yaitu pendekatan sejarah yang tidak terlepas dari pertumbuhan, perkembangan dari pondok pesantren sebagai objek penelitian.

b. Pendekatan fenomenologis, yaitu pendekatan yang digunakan dalam mengkaji objek penelitian yang berdasarkan pada fakta social yang ada.

\section{Teknik Pengumpulan Data}

Data-data yang dibutuhkan dalam penelitian digali melalui cara-cara sebagai berikut:

a. Observasi, merupakan cara mendapatkan informasi dengan meneliti langsung ke lapangan yang hendak diteliti.

b. Wawancara (interview), yaitu cara memperoleh data atau keterangan-keterangan melalui wawancara yang berdasarkan kepada tujuan penelitian. ${ }^{7}$ Dengan cara tanya jawab dan bertatap muka langsung dengan pihak yang berkompeten menjadi sumber data, yaitu Ketua Yayasan/Kyai, direktur TMI, Kepala Madrasah, Qismu' ta'lim (bagian Pengajaran) dan pihak lain yang dianggap dapat memberikan informasi berkait dengan kasus yang diteliti.

c. Kepustakaan dan dokumentasi, yaitu dengan melihat data-data yang ada di Pondok Pesantren Manba'ul 'Ulum serta dokumen dan bahan kepustakaan yang lain yang berhubungan dengan masalah yang diteliti.

\section{Analisis Data}

Menggunakan analisis kualitatif, yaitu data yang berhubungan kategorisasi, karakteristik atau sifat-sifat tertentu ${ }^{8}$, antara lain; induktif yaitu analisa terhadap data-data yang khusus untuk dibawa kepada kesimpulan umum.

\footnotetext{
${ }^{5}$ Sujono Sukanto, Pengantar Penelitian Hukum, 10.

${ }^{6}$ Noeng Muhadjir, Metode Penelitian Kualitatif, Cet, VII, (Yogyakarta: Pustaka Pelajar, 1998), 104.

${ }^{7}$ Sutrisno Hadi, Metodologi Research untuk Penulisan Papar, Tesis, dan Disertasi, Cet XXI (Yogyakarta: Andi Offset, 1992), 136.

${ }^{8}$ Muhammad Ali, Penelitian Kependidikan: Prosedur dan Strategi (Bandung: Angkasa, 1987), 81.
} 


\section{Teori Integrasi Kurikulum dan pengimplementasiannya di Pondok Pesantren Manba'ul Ulum Dukupuntang Cirebon}

Sebelum penulis menguraikan masing-masing dari teori yang penulis gunakan dalam integrasi kurikulum, lebih dulu penulis memaknai masing-masing dari kata teori, integrasi, dan kurikulum. Pertama teori, yaitu dalil (ilmu pasti); ajaran atau paham (pandangan) tentang sesuatu berdasarkan kekuatan akal (ratio); patokan dasar atau garis-garis dasar sains dan ilmu pengetahuan; pedoman praktek. ${ }^{9}$ Secara terminologis, pengertian umum dari teori adalah hipotesis yang belum terbukti atau spekulasi tentang kenyataan yang belum diketahui secara pasti. Akan tetapi penulis cenerug memihak pada bahwa suatu teori akan menjadi benar, sesuai dengan kenyataan atau faktuil jika data yang mendukungnya telah dikumpulkan dan data ini terbukti benar, dengan ata lain sekumpulan konvensi yang menekanka fakta bahwa teori-teori tidak diberikan atau ditentukan sebelumya oleh alam, data, atau proses lain yang menentukan. Dengan teori bisa membimbing ke arah pengumpulan atau observasi atas hubungan-hubungan empiris relevan yang belum diamati. ${ }^{10}$

Kedua integrasi dalam bahasa Indonesia merupakan pembakuan dari hasil penyerapan sedang dalam bahasa Inggris yaitu integration yang berarti pembauran hingga menjadi satu kesatuan yang utuh dan bulat. ${ }^{11}$ Secara istilah, integrasi memiliki sinonim dengan perpaduan, penyatuan atau penggabungan dari dua obyek atau lebih. Ketiga adalah arti kurikulum, secara etimologis, istilah curriculum dinyatakan sebagai istilah yang berasal dari bahasa Latin yakni curro atau currere dan ula atau ulums yang berarti "racecorurse" (lapangan/pacuan kuda, jarak tempuh lari, perlombaan, pacuan balapan, peredaran, gerak berkeliling, lapangan perlomban, gelanggang, kereta balap, dan lain-lain. Pengertian kuriulum yang sudah menjadi konsep salah satunya yang tertuang dalm Undang-Undang Sistem Pendidikan Nasional 2003 pasal 1 ayat 1, yang berbunyi: " Kurikulum adalah seperangat rencana dan pengaturan mengenai isi dan beban pelajaran serta cara yang digunakan sebagai pedoman

\footnotetext{
${ }^{9}$ Untuk lebih memudahkan pemahaman dalam menangkap istilah bahasa maka penulis membagi dalam dua arti, pertama etimologis dan terminologis - lughotan wa istilahan, salah satunya adalah arti kamus. Lihat pada Pius A Partanto \& M. Dahlan al-Barry, Kamus Ilmiah Populer (Surabaya: Arkola, 1994), 746.

${ }^{10}$ Calvin S. Hall \& Gardner Lindzey, Teori-Teori Psikodinamik (Klinis) (Yogyakarta: Kanisius, 1993), $29-31$.

${ }^{11}$ Departemen Pendidika dan Kebudayaan, Kamus Besar Bahasa Indonesia (Jakarta: Balai Pustaka, 1990), 335.
} 
penyelenggaraan kegiatan belajar mengajar". ${ }^{12}$, dalam pengintegrasiannya ada beberapa model, yaitu:

\section{Sharred Curriculum, Pengintegrasian di dalam Satu Disiplin Ilmu}

Ditinjau dari namanya saja bahwa arti kata dari sharred yaitu berarti kerjasama, sebagai salah satu model dalam kurikulum tepadu yang pola skuen materinya diatur dengan cara menggabungkan materi yang ada pada dua bidang studi atau mata pelajaran. Konsep (concepts), sikap (attitudes), dan keterampilan (skills) yang memiliki kesamaan atau overlapping digabungkan untuk saling mendukung. Misalkan dalam konteks pemaduan anatara Iptek dan Imtaq, konsep, sikap, dan keterampilan yang terdapat dalam kurikulum salah satu mata pelajaran Iptek (Biologi, fisika, dan Kimia) digabungkan dengan konsep, sikap, dan keterampilan yang sama atau berdekatan yang terdapat di dalam mata pelajaran Pendidikan Agama Islam (al-Qur'an-hadis, Aqidah-Akhlak, Fiqh, dan SKI). ${ }^{13}$

\section{Corelated Curriculum, Pengintegrasiian Beberapa Disiplin Ilmu}

Ilmu pada mulanya adalah tidak terpisah-pisah seperti sekarang yang terdiri dari berbagai disiplin ilmu dan menemukan spesifikasinya. Namun demikian, meskipun telah terjadi spesifikasi pada ilmu yang pada awalnya adalah mutlak tak terpisah atau terbagi dalam kelompok dan jenis pada hakikatnya adalah masih berhubunga erat dangan yang lainnya. Demikian pula dengan correlated curriculum, yaitu suatu bentuk kurikulum yang menunjukkan adanya ketersalingan (mutual) antara satu mata pelajaran dengan mata pelajaran lainnya dan disusun sedemikian rupa sehingga yang satu memperkuat yang lain dan saling melengkapinya akan tetapi tetap memperhatikan ciri (karakteristik) tiap bidang studi tersebut.

Beberapa cara untuk mengkorelasikan antar mata pelajaran adalah sebagai berikut:

a. Insidental, artinya secara tidak ada perencanaan sebelumnya bahwa satu mata pelajaran ada hubungan dengan mata pelajaran lainnya. Sebagai contoh: bidang studi IPA (Sains). Dalam bidang ini dalam penyampainnya demi pemahaman dan penguasaan materi, yaitu disinggung pula di dalamnya tentang Geografi, Antrophologi, dan sebagainya. Pada materi tafsir al-Qur'an di dalamnya juga terdapat keterangan yang berbicara tentang hukum Islam seperti nikah, berarti di sini ada keterkaitan dengan materi pelajaran fiqh.

${ }^{12}$ Syaifuddin Sabda, Model Kurikulum Terpadu IPTEK \& IMTAQ (Jakarta: PT. Ciputat Press Group, 2006), 21, 27. juga dalam Oemar Hamalik, Kurikulum dan Pembelajaran (Jakarta: Bumi Aksara, 1995), 17-18.

${ }^{13}$ Syaifuddin Sabda, Model Kurikulum Terpadu IPTEK \& IMTAQ, 81. 
b. Korelasi sistematis, yaitu korelasi yang disusun dan direncanakan oleh guru. Seperti materi pelajaran Sejarah Kebudayaan Islam yang dibahas dalam Hadis.

c. Korelasi informal, korelasi ini dapat berjalan dengan cara antara beberapa guru saling bekerja sama, seperti tiga mata pelajaran -Fiqh, Qu'an Hadis, dan SKI- yang dipegang oleh guru masing-masing bersepakat untuk saling mengkaitkan dengan pelajaran tersebut pada saat menyampaikan materi atau mengajar.

d. Korelasi formal, korelasi ini sebenarnya telah direncanakan oleh guru atau team secara bersama-sama, seperti mata pelajaran yang berkaitan dengan Fiqh, Qur'an Hadis, dan Akhlak diramu menjadi satu kesatuan untuk memecahkan persoalan yang sedang terjadi di tengah-tengah masyarakat, seperti masalah miras (minuman keras), togel (totoan gelap), dan fenomena-fenomena sosial lainnya.

e. Batas mata pelajaran disatukan dan difungsikan, yaitu dengan menghilangkan batasan masing-masing mata pelajaran tersebut. Istilah lain untuk penyebutan ini adalah Broad Field.

Ada lima macam Broad Field di dalam kurikulum, yaitu:

- Ilmu Pengetahuan Sosial, pada mata pelajaran ini adalah merupakan peleburan dari mata pelajaran ekonomi, koperasi, sejarah, geografi, dan sejenisnya.

- Bahasa, ini merupakan peleburan dari mata pelajaran membaca, menulis mengarang, menyimak, sastra, apresiasi, dan pengetahuan bahasa.

- Ilmu Pengetahuan Alam adalah peleburan dari mata pelajaran fisika, biologi, kimia, astronomi (IPBA), dan kesehatan.

- Matematika, yaitu pelebutran dari aljabar, aritmetika, geometri, dan statistic.

- Kesenian, peleburan dari seni tari, seni musik, seni suara, seni pahat, dan seni drama.

\section{Integrated Curriculum, Pengintegrasian di dalam Satu dan Beberapa}

Dalam kebahasaan secara istilah akan pengertian integrasi sebenarnya memiliki kesamaan (sinonim) dengan kata perpaduan, penyatuan, atau penggabungan dari dua obyek atau lebih. ${ }^{14}$ Begitupula dengan apa yang dikemukakan dalam Kamus Besar Bahasa

\footnotetext{
${ }^{14}$ Seperti dikemukakan oleh Wedawaty, 1990: 26 dalam Trianto, Model Pembelajaran Terpadu, Teori dan Praktek (Jakarta: Prestasi Pustaka, 2007), 38.
} 
Indonesia Poerwadarminta, bahwa integrasi adalah penyatuan supaya menjadi satu kebulatan atau menjadi utuh.

Terkait dengan masalah yang sedang penulis garap dalam tesis ini adalah integrated curriculum, yaitu berkenaan dengan pelajaran yang dipusatkan pada suatu masalah atau topik tertentu, misalnya suatu masalah di mana semua mata pelajaran dirancang dengan mengacu pada topik tertentu.

Penyampaian materi melalui kurikulum jenis integrated curriculum ini dalam bnetuk unit. Dimaksud dengan unit itu mengandung suatu soal atau problem yang luas yang dipelajari murid selama beberapa minggu atau beberapa bulan, malahan kadang-kadang sepanjang tahun. $^{15}$

Manfaat dan kelebihan dari apa yang dimiliki dari Integrated Curriculum pada skala praktisnya, antara lain:

a. Segala permasalahan yang dibicarakan dalam unit sangat bertalian erat.

b. Sangat sesuai dengan perkembangan modern tentang belajar-mengajar.

c. Memungkinkan adanya hubungan antara sekolah dan masyarakat.

d. Sesuai dengan ide demokrasi, di mana siswa dirangsang untuk berpikir sendiri atau mandiri, bekerja sendiri dan memikul tanggung jawab bersama dan bekerja sama dalam kelompok.

e. Penyajian bahan disesuaikan dengan kesanggupan dan kemampuan individu, minat, dan kematangan siswa baik secara individu maupun secara kelompok. ${ }^{16}$

Pengembangan kurikulum mengandung arti perubahan, pergantian (alteration) atau modifikasi terhadap susunan yang ada. Perubahan yang positif dapat menghasilkan pengembangan, maka ia harus memiliki karakteristik: (1) perubahan harus bermanfaat dalam arti bahwa perubahan harus sengaja dan mempunyai arah untuk mencapai target dan tujuan tertentu, (2) perubahan harus direncanakan dalam arti bahwa perubahan harus merupakan rangkaian langkah-langkah sistematis dan berurutan yang menuju target dan dilaksanakan dalam periode waktu tertentu, (3) perubahan harus progresif dalam arti bahwa perubahan harus secara positif membawa perbaikan di masa yang akan datang. ${ }^{17}$

\footnotetext{
15 Iskandar Wiryokusumo dan Usman Mulyadi, Dasar-Dasar Pengembangan Kurikulum (Jakarta: Bima Aksara, 1988), 18.

${ }^{16}$ Hal ini telah dijelaskan oleh Nurdin dan Usman dalam Trianto, Model Pembelajaran Terpadu, Teori dan Praktek, 39.

${ }^{17}$ Abdul Rachman Shaleh, Madrasah dan Pendidikan Anak Bangsa, 191-192.
}

Al-Tarbawi Al-Haditsah: Jurnal Pendidikan Islam 
Demikian halnya dengan kurikulum yang di gunakan pada lembaga pendidikan (SMP, SMK, MA) yang berada dalam naungan Pondok Pesantren Manba'ul 'Ulum berpedoman pada kurikulum umum dan kurikulum pondok al-Amin yang dikembangkan dan dimodifikasi oleh pengelola Pondok Pesantren Manba'ul 'Ulum yang diharapkan menjadi nilai tambah bagi lulusannya di masa mendatang.

\section{a. Bahan Pembelajaran}

\section{1) Pengurangan dan Kolaborasi Mata Pelajaran}

Pihak penyelenggara pendidikan di pondok ini menyadari akan keterbatasan santri untuk menguasai semua mata pelajaran pondok sebagaimana santri Gontor dan memahami mata pelajaran umum seperti halnya siswa setingkat mereka di luar pondok.

\section{2) Pemadatan Materi}

Integrasi kurikulum pondok dan madrasah juga dijalankan dengan pemadatan materi pelajaran. Hal ini terkait erat dengan pengurangan jumlah jam pelajaran yang akan dibahas lebih lanjut. Pada tema pemadatan materi ini pondok menekankan pada dewan guru dan santri untuk dapat memenuhi fungsi masing-masing dalam proses belajar-mengajar. tema-tema sentral harus menjadi prioritas ustadz untuk disampaikan, santri harus aktif membaca dan mempelajari materi yang tidak diajarkan oleh ustadznya di kelas. Pemadatan materi ini memiliki konsekuensi akan keharusan dewan guru meluangkan waktu di malam atau sore hari untuk menerima kehadiraan santri dalam menanyakan pemahaman santri yang kurang dari apa-apa yang telah disampaikan ustadz di kelas sebelumnya.

3) Pengurangan Alokasi Waktu

Pelaksanaan KBM di sekolah-sekolah pada umumnya tiap jam pelajaran berjalan 45 menit. Di pondok ini ditemui bahwa mata pelajaran umum dan pondok diajarkan 40 menit per jam pelajaran. Bahkan pada pelajaran yang dilaksanakan pada jam pelajaran setelah sholat dhuhur yaitu ke-8 dan ke-9 hanya menggunakan 35 menit per mata pelajaran.

\section{4) Pengurangan Jumlah Pertemuan Jam Mata Pelajaran}

Juga didapati pengurangan jumlah pertemuan baik pada pelajaran umum maupun pondok. Sebagai contoh mata pelajaran matematika yang seharusnya 6 kali pertemuan dalam seminggu menjad 4 pertemuan dalam seminggu. Pengurangan ini didasari pemikiran bahwa dengan mempersempit pertemuan dapat memberikan peluang bagi mata pelajaran lain, sedang materi yang tertinggal dalam tiap pertemuan dapat dibahas dengan diskusi sesama santri atau dengan 
mengundang dewan guru yang bersangkutan di luar jam belajar di kelas. Dalam kurikulum pondok pesantren Manba'ul 'Ulum, mata pelajaran yang akan disampaikan kepada santri disusun dalam paket program berdasarkan tingkat pendidikan. daftar mata pelajaran da tingkat pendiikan dapat dilihat pada daftar berikut:

\begin{tabular}{|c|c|c|c|c|c|c|c|c|}
\hline No & Pelajaran & $\begin{array}{c}\text { Kelas } \\
\text { I }\end{array}$ & $\begin{array}{c}\text { Kelas } \\
\text { II }\end{array}$ & $\begin{array}{c}\text { Kelas } \\
\text { III }\end{array}$ & $\begin{array}{c}\text { Kelas } \\
\text { IV }\end{array}$ & $\begin{array}{c}\text { Kelas } \\
\text { V }\end{array}$ & $\begin{array}{c}\text { Kelas } \\
\text { VI }\end{array}$ & $\begin{array}{c}\text { Kelas } \\
\text { Intensif }\end{array}$ \\
\hline 1 & B. Arab & $X$ & $\mathrm{X}$ & & & & & $\mathrm{X}$ \\
\hline 2 & Shorof & & $\mathrm{X}$ & $\mathrm{X}$ & & $\mathrm{X}$ & & \\
\hline 3 & Faroidh & & & & & $\mathrm{X}$ & & \\
\hline 4 & Khoth & $\mathrm{X}$ & $\mathrm{X}$ & $\mathrm{X}$ & $\mathrm{X}$ & & & $\mathrm{X}$ \\
\hline 5 & Muthola'ah & $\mathrm{X}$ & $\mathrm{X}$ & $\mathrm{X}$ & $\mathrm{X}$ & $\mathrm{X}$ & $\mathrm{X}$ & \\
\hline 6 & $\mathrm{H}$ a dis & & $\mathrm{X}$ & $\mathrm{X}$ & $\mathrm{X}$ & $\mathrm{X}$ & & $\mathrm{X}$ \\
\hline 7 & Mahfudzot & $\mathrm{X}$ & $\mathrm{X}$ & $\mathrm{X}$ & $\mathrm{X}$ & & $\mathrm{X}$ & $\mathrm{X}$ \\
\hline 8 & Tarbiyah & & & $\mathrm{X}$ & $\mathrm{X}$ & $\mathrm{X}$ & $\mathrm{X}$ & \\
\hline 9 & Kifayatul Atqiya & & & & $\mathrm{X}$ & $\mathrm{X}$ & & \\
\hline 10 & In s y a' & & $\mathrm{X}$ & $\mathrm{X}$ & $\mathrm{X}$ & $\mathrm{X}$ & $\mathrm{X}$ & \\
\hline 11 & Ushul Fiqh & & & $\mathrm{X}$ & $\mathrm{X}$ & $\mathrm{X}$ & & \\
\hline 12 & Jurumiyyah & & & $\mathrm{X}$ & $\mathrm{X}$ & & & \\
\hline 13 & Diinul Islam & & & $\mathrm{X}$ & $\mathrm{X}$ & & & \\
\hline 14 & Tarikh Islam & $\mathrm{X}$ & $\mathrm{X}$ & $\mathrm{X}$ & $\mathrm{X}$ & $\mathrm{X}$ & & $\mathrm{X}$ \\
\hline 15 & Tauhid & $\mathrm{X}$ & $\mathrm{X}$ & & & $\mathrm{X}$ & & $\mathrm{X}$ \\
\hline 16 & Fiqh & $\mathrm{X}$ & $\mathrm{X}$ & & & $\mathrm{X}$ & $\mathrm{X}$ & \\
\hline 17 & $\mathrm{Nahu}$ & & $\mathrm{X}$ & $\mathrm{X}$ & $\mathrm{X}$ & $\mathrm{X}$ & & \\
\hline 18 & Balaghoh & & & & $\mathrm{X}$ & $\mathrm{X}$ & $\mathrm{X}$ & \\
\hline 19 & Mantiq & & & & & & $\mathrm{X}$ & \\
\hline 20 & Ta'lim Muta'lim & & $\mathrm{X}$ & & & & & \\
\hline 21 & Tajwid & $\mathrm{X}$ & $\mathrm{X}$ & & & & $\mathrm{X}$ & \\
\hline 22 & Biologi & $\mathrm{X}$ & $\mathrm{X}$ & $\mathrm{X}$ & & & & \\
\hline 23 & Fisika & $\mathrm{X}$ & $\mathrm{X}$ & $\mathrm{X}$ & & & & \\
\hline
\end{tabular}




\begin{tabular}{|c|c|c|c|c|c|c|c|c|}
\hline 24 & Sosiologi & & & & $\mathrm{X}$ & & $\mathrm{X}$ & \\
\hline 25 & K T I & & & & & & $X$ & \\
\hline 26 & Tafsir & $X$ & $X$ & $X$ & $X$ & $X$ & $X$ & $\mathrm{X}$ \\
\hline 27 & Matematika & $\mathrm{X}$ & & & $X$ & $X$ & & \\
\hline 28 & Ekonomi & $X$ & $X$ & $X$ & $X$ & & & \\
\hline 29 & B. Inggris & $\mathrm{X}$ & $\mathrm{X}$ & $\mathrm{X}$ & $\mathrm{X}$ & $\mathrm{X}$ & $\mathrm{X}$ & $\mathrm{X}$ \\
\hline 30 & Dictation & & & & $\mathrm{X}$ & $X$ & $X$ & \\
\hline 31 & Compotation & & & & $\mathrm{X}$ & $\mathrm{X}$ & $X$ & \\
\hline 32 & Grammar & & & $X$ & $X$ & $X$ & $X$ & \\
\hline 33 & Sejarah & & $X$ & & $\mathrm{X}$ & $\mathrm{X}$ & $X$ & \\
\hline 34 & Mengarang & $X$ & $\mathrm{X}$ & $\mathrm{X}$ & $\mathrm{X}$ & & & \\
\hline 35 & B. Indonesia & $X$ & $\mathrm{X}$ & $X$ & $\mathrm{X}$ & & $X$ & \\
\hline 36 & Tarjamah & & $X$ & $X$ & $\mathrm{X}$ & & $X$ & \\
\hline 37 & Geografi & & $X$ & $X$ & & & & \\
\hline 38 & Sastra & & & & $\mathrm{X}$ & $\mathrm{X}$ & & \\
\hline 39 & I m $1 \mathrm{a}^{\prime}$ & $\mathrm{X}$ & $\mathrm{X}$ & $\mathrm{X}$ & $\mathrm{X}$ & & $\mathrm{X}$ & \\
\hline
\end{tabular}

Tabel 8. Kurikulum Madrasah dan Pondok Pesantren Manba'ul 'Ulum

\section{b. Segi Pembelajaran}

Pembelajaran diartikan sebagai acara dari peristiwa eksternal yang dirancang oleh guru guna mendukung terjadinya kegiatan belajar yang dilakukan oleh siswa. Dengan demikian, kegiatan pembelajaran dilukiskan sebagai upaya guru yang tujuannya membantu siswa untuk belajar. Kegiatan pembelajaran lebih menekankan kepada semua peristiwa yang dapat berpengaruh secara langsung kepada efektifitas belajar siswa sebagai suatu usaha yang bersifat sadar tujuan yang dengan sistematik terarah pada perubahan tingkah laku. Perubahan yang dimaksud menunjuk pada suatu proses yang harus dilalui. Tanpa proses perubahan tidak mungkin terjadi dan tujuan tak dapat dicapai. Dengan kata lain pembelajaran adalah upaya guru agar terjadi peristiwa belajar yang dilakukan siswa. Peristiwa guru mengajar dan siswa belajar sebagai peristiwa proses pembelajaran senantiasa dipengaruh oleh beberapa hal, antara lain: 
1. Kompetensi dasar, meliputi; bukan hanya domain kognitif saja tetapi juga afektif, dan psikimotorik, yaitu perubahan pada diri anak, dari tidak tahu menjadi tahu, dari tidak bersikap menjadi dapat menilai atau dapat membedakan dari tidak dapat melakukan sampai menjadi dapat mempraktekkan dan dapat mengerjakannya.

2. Materi/bahan ajar, yaitu terstruktur dalam kajian rumpun mata pelajaran, baik meliputi ruang lingkup sekuensial maupun tingkat kesulitannya.

3. Sumber belajar, untuk menjadikan peristiwa pembelajaran yang kontekstual, artinya yang relevan, terpilih, dan tepat guna sesuai dengan pencapaian kompetensi dasar yang ditetapkan.

4. Media dan fasilitas belajar, termasuk ruang kelas dan penciptaan lingkungan yang kondusif yang menjadikan peristiwa belajar menjadikan dinamis dan menyenangkan. Di sini perlunya dipertimbangkan jumlah siswa, alokasi waktu, dan tersedianya alat peraga dan pemilihan metode yang akan dipergunakan.

5. Siswa yang belajar, perlu diperhatikan kemampuan, usia perkembangan, latar belakang, motivasi, dan kebutuhan siswa.

6. Guru yang mengelola pembelajaran, yaitu dilihat dari kompetensinya dalam tekhnik mengajar kebiasaannya, pandangan hidup, latar belakang pendidikan, dan kerja sama dengan teman sejawat sesama guru. ${ }^{18}$

Oleh karena itu, Pondok Pesantren Manba'ul 'Ulum dalam proses pembelajarannya menganut sistem 24 jam, dalam artian selama santri berada di pondok mereka tidak terlepas dari nilai-nilai pendidikan. Mereka diharapkan selain dibentuk dengan proses belajar mengajar di kelas juga mendapat masukan yang bermanfaat dari kehidupan di luar kelas.

Apa yang mereka lihat, dengar, dan rasakan di pondok adalah rangkaian program pendidikan. selain pembentukan intelektual di kelas, spiritual dengan pengajian dan ceramah di masjid, santri juga dibiasakan untuk hidup enerjik, sehat dengan berolahraga. Bahkan untuk olah raga ini dibuat jadwal khusus untuk lari pagi yang seluruh santri diwajibkan mengikutinya. Integrasi di sini memunculkan kesatuan gerak fisik dan non fisik.

Metode pengajaran di pondok pesantren ini berangkat dari kaidah-kaidah pengajaran sebagai berikut:

${ }^{18}$ Abdul Rachman Shaleh, Madrasah dan Pendidikan Anak Bangsa., 211-222.

Al-Tarbawi Al-Haditsah: Jurnal Pendidikan Islam

Vol. 2, No. 2, Desember 2017 
Diawali dari yang dapat diamati menuju kepada sesuatu yang rasional, dari hal yang sudah diketahui kepada yang belum diketahui.

a. Dari contoh-contoh menuju kepada kaidah dan definisi.

b. Berangsur-angsur dari yang berdiri sendiri menuju kepada yang tersusun.

c. Berangsur-angsur dari pengambilan pengertian eksperimen menuju kepada penarikan kesimpulan pandangan dan dalil. ${ }^{19}$

Untuk menuju tujuan pendidikannya, Pondok Pesantren Manba'ul 'Ulum menerapkan beberapa metode pendidikan seperti:

1. Metode pembiasaan, terutama diorientasikan untuk character buldiing berupa pembiasaan kesadaran disiplin dan moral.

2. Metode Learning by instruction, digunakan dalam aspek kehidupan pesantren agar santri dapat merasakan nilai-nilai pendidikan dan sekaligus sebagai sarana efektifitas realisasi nilai-nilai pesantren.

3. Learning by doing, pendidikan yang didapatkan diharapkan dapat diaplikasikan oleh santri dalam kehidupan mereka secara langsung.

4. Metode pendidikan dengan keteladanan (uswatun hasanah), para pendidik dan peserta didik sama-sama berupaya untuk dapat menjadi teladan bagi diri mereka sendiri dan orang lain dengan sadar dan ikhlas bahwa perilaku tersebut merupakan kebutuhan masing-masing individu.

5. Metode kritik (atthoriqoh an-naqd), bahwasanya ustadz dan santri merupakan pribadi yang terbuka terhadap kritik dan siap mengkritik dan menerima kritikan.

Kegiatan setiap hari diusahakan untuk teratur sehingga mudah dalam pengontrolan dan membiasakan santri untuk disiplin dan menghargai waktu, pelaksanaan program tersebut sebesar mungkin diusahakan-didasari oleh kesadaran yang muncul dari individu santri, dan untuk memotivasinya pesaantren juga memberikan konseling baik dari kakak kelas atau dari ustadz langsung. Kegiata harian dan mingguan santri dapat dilihat pada daftar sebagai berikut:

\begin{tabular}{|l|c|l|}
\hline No & Jam & \multicolumn{1}{|c|}{ Kegiatan } \\
\hline 1. & $03.30-04.30$ & Bangun tidur, sholat malam, dzikir al-ma'tsurot \\
\hline 2. & $04.30-05.00$ & Sholat Shubuh (sesuai jadwal sholat) \\
\hline
\end{tabular}

${ }^{19}$ Mahmud Yunus, At-Tarbiyyah wa At-Ta'lim 13-18.t.t. 


\begin{tabular}{||l|l|l||}
\hline 3. & $05.00-05.30$ & Hafalan al-Quran \\
\hline 4. & $05.30-06.00$ & Senam pagi \\
\hline 5. & $06.00-06.30$ & Mandi, makan, dan persiapan masuk kelas \\
\hline 6. & $06.30-06.45$ & Sholat Dhuha dan asma'ul husna \\
\hline 7. & $06.45-07.00$ & Demonstrasi bahasa \\
\hline 8. & $07.00-13.30$ & Belajar di kelas \\
\hline 9. & $13.30-15.15$ & ISMA (di komplek pesantren) \\
\hline 10. & $15.15-16.00$ & Sholat Ashar \\
\hline 11. & $16.00-17.00$ & Pengajian kitab/kursus (Kegiatan ekstra kurikuler) \\
\hline 12. & $17.00-17.30$ & MCK \\
\hline 13. & $17.30-18.00$ & Ma'tsurot/persiapan hafalan \\
\hline 14. & $18.00-18.30$ & Sholat Maghrib \\
\hline 15. & $18.30-19.00$ & Pengajian al-Quran \\
\hline 16. & $19.00-19.30$ & Sholat Isya \\
\hline 17. & $19.30-20.00$ & Makan malam \\
\hline 18. & $20.00-21.30$ & Belajar malam \\
\hline 19. & $21.30-21.45$ & Taushiyah \\
\hline 20. & $21.45-03.30$ & Istirahat/tidur \\
\hline
\end{tabular}

Tabel 9. Jadwal Kegiatan Harian Santri Pondok Pesantren Manba'ul 'Ulum

Tabel di atas menjelaskan kegiatan santri dalam 24 jam. Dari bangun tidur sampai tidur kembali. Jadwal tersebut dilaksanakan secara konsekuen oleh pihak penyelenggara pendidikan di pondok Pesantren Manba'ul 'Ulum, peran serta santri dalam menegakkan disiplin amat ditekankan didasari oleh kesadaran akan perlunya hidup teratur dan penghargaan terhadap waktu.

Selain menentukan jadwal kegiatan harian lembaga pendidikan pondok Manba'ul 'Ulum juga menformulasi sebuah jadwal mingguan sebagai mana tertulis di bawah ini:

\begin{tabular}{|l|l|c|c|}
\hline No & H a r i & Waktu & Kegiatan \\
\hline \hline 1. & Sabtu & $20.00-21.30$ & Muhadloroh tiga bahasa dan MC \\
\hline
\end{tabular}

Al-Tarbawi Al-Haditsah: Jurnal Pendidikan Islam 


\begin{tabular}{|l|l|l|l||}
\hline 2. & Minggu & $16.00-17.00$ & Ta'lim dan Ceramah Ilmiah \\
\hline 3. & Minggu & $19.30-20.30$ & Ta'lim dan Ceramah Ilmiah \\
\hline 4. & Senin & $07.00-07.45$ & Upacara \\
\hline 5. & Kamis & $19.30-21.00$ & $\begin{array}{l}\text { Musawarah Pengurus: evaluasi program kerja } \\
\text { dan koordinasi pelaksaan kegiatan }\end{array}$ \\
\hline 6. & Kamis & $14.00-15.30$ & Pramuka \\
\hline 7. & Jum'at & $06.30-08.00$ & Kerja bakti \\
\hline
\end{tabular}

Tabel 10. Jadwal Kegiatan Mingguan Santri Pondok Pesantren Manba'ul 'Ulum

Untuk mendukung program integrasi kurikulum di pondok ini, pihak pondok selain melengkapi diri dengan sarana dan prasarana juga membuat aturan dan kebijaksanaan yang menjadi pertimbangan pengambilan tindakan bila timbul faktor-faktor yang dianggap dapat mengganggu proses integrasi. Seperti aturan tentang:

a. Waktu masuk kelas mulai 07.00-13.30 WIB

b. Berpakain seragam sesuai dengan ketentuan harinya, bersepatu, ikat pinggang serta berpeci/kerudung.

c. Tidak diperkenankan berkeliaran di luar kelas pada saat KBM berlangsung.

d. Tidak diperkenankan mengambil alat sekolah pada saat KBM.

e. Waktu perizinan untuk tidak masuk kelas dan tidak bepakaian seragam mulai setelah sholat Shubuh sampai jam 07.00 WIB.

f. Bagi santri yang bertugas jaga malam harus masuk kelas mulai jam pelajaran ke-4 sampai jam pelajaran ke-9.

g. Tidak diperkenankan istirahat di dalam kamar pada waktu istirahat.

h. Bagi yang sakit harus tinggal di Poskestren (Pos Kesehatan Pesantren).

i. Absen harus dikembalikan ke kantor TMI setelah usai KBM.

j. Bila dalam 10 menit guru belum hadir, agar dicari guru pengganti di kantor TMI.

k. Ketua kelas dan wakil bertanggun jawab akan keberhasilan kelas.

1. Tidak diperkenankan keluar masuk lewat pintu belakang kelas.

m. Tidak diperkenankan menerima tamu pada saat KBM berlangsung. 
n. Syarat mengikuti ujian harus memenuhi $75 \%$ kehadiran.

Dalam melaksanakan evaluasi pembelajaran di Pondok Pesantren Manba'ul 'Ulum yaitu dilaksanakan dengan menggunakan sistem semester. Setiap enam bulan diadakan ujian yang dilaksanakan dengan berbagai macam cara, seperti ujian tertulis, ujian lisan, dan ujian dalam bentuk praktek mengajar, dan sebagainya. Ujian dapat pula dilaksanakan dengan berbagai kombinasi cara-cara tersebut, supaya maksud dan tujuan penyelenggara ujian dapat tercapai, maka perlu diadakan beberapa kali ujian, yaitu ujian harian dan ujian semester.

Cara ujian yang digunakan disesuaikan dengan sifat kegiatan pendidikan. ujian dilaksanakan dengan maksud untuk:

1. Menilai apakah seorang santri telah memahami bahan yang diujikan.

2. Mengelempokkan santri berdasarkan kemampuannya.

3. Menilai apakah bahan yang diujikan telah sesuai serta cara menyajikannya telah cukup baik, sehingga para santri dengan usaha yang wajar dapat memahami bahan tersebut.

Dalam penilain yang sesuai dengan maksud dan tujuan yang telah disebutkan di atas adalah sistem penilaian relative terhadap kemampuan santri yang lain dalm kelasnya. Ini berarti bahwa prestasi seluruh santri dalam suatu kelas digunakan sebagai dasar penilaian. Dalam hal ini digunakan anggapan bahwa dalam suatu kelompok santri, pasti terdapat santri yang kemampuannya amat baik, cukup, dan kurang.

Evaluasi hasil studi santri dilaksanakan setiap semester. Pada setiap semester nilai yang dimasukkan dalam raport adalah hasil perhitungan antara rata-rata hasil ulangan harian, mid semester dengan hasil ulangan semester. Penentuan kenaikan kelas dan kelulusan santri dilakukan dengan mempertimbangkan nilai yang diperoleh santri selama studi dan reputasi positif yang dibangun santri.

\section{c. Segi Hasil Integrasi}

Dalam kurikulum terintegrasi atau terpadu -integrated curriculum- ini, batas-batas diantara semua mata pelajaran sudah tidak terlihat sama sekali, karena semua mata pelajaran sudah dirumuskan dalam bentuk masalah atau unit. Jadi semua mata pelajaran telah terpadu sebagai satu kesatuan yang bulat.

Ciri-ciri kurikulum terintegrasi ini adalah sebagai berikut:

1) Berdasarkan filsafat pendidikan demokrasi. 
2) Berdasarkan psikologi belajar Gestalt atau organismik.

3) Berdasarkan landasan sosiologis dan sosial kultural.

4) Berdasarkan kebutuhan, minat, dan tingkat perkembangan atau pertumbuhan siswa.

5) Bentuk kurikulum ini tidak hanya ditunjang oleh semua mata pelajaran atau bidang studi yang ada, tetapi lebih luas, bahkan mata pelajaran atau bidang studi baru dapat saja muncul dan dimanfaatkan guna pemecahan masalah.

6) Sistem penyampaian menggunakan sistem pengajaran unit, baik unit pengalaman (experience unit) atau unit pelajaran (subject matter unit).

7) Peran guru sama aktifnya dengan peran murid. Bahkan peran murid lebih menonjol dalam kegiatan belajar mengajar dan guru bertindak selaku pembimbing. ${ }^{20}$

Di atas telah diuraikan tentang faktor-faktor penunjang integrasi (integrasi kurikulum), yaitu lingkungan, sumber daya manusia, dan budaya yang kemudian disebut dengan sosial-budaya. Konkritnya bahwa integrasi kurikulum atas dukungan sosial-budaya tersebut menghasilkan:

a. Kurikulum harus disusun berdasarkan kondisi sosial-budaya masyarakat. Kurikulum disusun bukan saja harus berdasarkan nilai, adat istiadat, cita-cita dari masyarakat, tetapi juga harus berdasarkan semua dimensi kebudayaan seperti kehidupan keluarga, ekonomi, politik, pendidikan, dan sebagainya.

b. Karena kondisi soaial-budaya senantiasa berubah dan berkembang sejalan dengan perubahan masyarakat, maka kurikulum harus disusun dengan memperhatikan unsur fleksibilitas dan bersifat dinamis, sehingga kuriklulum tersebut senantiasa relevan dengan masyarakat. Konsekuensi logisnya, pada waktunya perlu diadakan perubahan dan revisi kurikulum, sesuai dengan perkembangan dan perubahan sosial-budaya yang ada saat itu.

c. Program kurikulum harus disusun dan mengandung materi sosial-budaya dalam masyarakat. Ini bukan hanya dimaksudkan untuk membudayakan anak didik, tetapi sejalan dengan mengawetkan kebudayaan itu sendiri. Kemajuan dalam bidang teknologi akan memberikan bahan yang memadai dalam penyampaian teknologi baru pada para siswa, yang sekaligus mempersiapkan para siswa tersebut agar mampu hidup dalam teknologi itu.

${ }^{20}$ Oemar Hamalik, Dasar-dasar Pengembangan Kurikulum (Bandung: Remaja Rosdakarya, 2007), 158-159. 
Dengan demikian, lembaga pendidikan benar-benar dapat mengemban peran dan fungsinya sebagai lembaga modernisasi.

d. Kurikulum harus disusun berdasarkan kebudayaan nasional yang belandaskan pada falsafah Pancasila, yang mencakup perkembangan kebudayaan daerah. Integritas kebudayaan nasional akan tercermin dalam isi dan organisasi kurikulum, karena sistem pendidikan kita bermaksud mebudayakan anak didik kita berdasarkan kebudayaan masyarakat dan bangsa kita sendiri.

\section{Kesimpulan}

1. Faktor-faktor yang menimbulkan perlunya integrasi kurikulum pesantren dan madrasah di Pondok Pesantren Manba'ul 'Ulum adalah adanya pemahaman akan kesatuan ilmu agama dan umum yang diaplikasikan dalam satu lembaga pendidikan tanpa memilah anatara mata pelajaran berbasis ilmu agama dan mata pelajaran berbasis ilmu umum.

2. Penerapan integrasi kurikuum pesantren dan madrasah di Pondok Pesantren Manba'ul 'Ulum dari aspek bahan pembelajaran, yaitu dengan pengurangan dan kolaborasi mata pelajaran, pemadatan materi, pengurangan alokasi waktu, dan pengurangan jumlah pertemuan pelajaran. Sebagaimana terapan dari Sharred Curriculum (pengintegrasian di dalam satu disiplin ilmu),Correlated Curriculum (pengintegrasian Beberapa disiplin ilmu),dan Integrated Curriculum (pengintegrasian di dalam satu dan beberapa disiplin ilmu). Dari aspek proses pembelajaran memungsikan program belajar full day, mengefesienkan jam belajar di luar kelas, belajar individual, dan bimbingan ustadz. Dari aspek evaluasi pembelajaran menerapkan evaluasi yang komprehensif, baik lisan maupun tertulis dengan menekankan penilaian yang menyeluruh.

3. Integrasi kurikulum pesantren dan madrasah di Pondok Pesantren Manba'ul 'Ulum Sindangmekar Dukupuntang Cirebon Jawa Barat dijadikan sebagai alternatif pengembangan kurikulum pesantren dan madrasah dengan mempertimbangkan tiga aspek sebagai berikut: pendukung antaralain; lingkungan, Sumber Daya Manusia dan budaya.

4. Kurikulum diperlukan untuk membantu guru dalam mengembangkan pengetahuan, sikap, nilai, dan keterampilan dari berbagai bahan kajian dan pelajaran yang diperoleh siswa sesuai dengan jenjang dan satuan pendidikannya. 


\section{DAFTAR PUSTAKA}

Ali, Muhammad. 1987. Penelitian Kependidikan: Prosedur dan Strategi. Bandung: Angkasa.

Azra, Azumardy. 1999. Pendidikan Islam: Tradisi dan Modernisasi Menuju Milenium Baru. Jakarta: Logos.

Departemen Pendidika dan Kebudayaan, 1990. Kamus Besar Bahasa Indonesia. Jakarta: Balai Pustaka.

Hadi, Sutrisno. 1992. Metodologi Research untuk Penulisan Papar, Tesis, dan Disertasi. Cet. XXI. Yogyakarta: Andi Offset.

Hamalik, Oemar. 1995. Kurikulum dan Pembelajaran. Jakarta: Bumi Aksara. 2007. Dasar-dasar Pengembangan Kurikulum, Bandung: Remaja Rosdakarya.

Muhadjir, Noeng. 1998. Metode Penelitian Kualitatif Cet. VII. Yogyakarta: Pustaka Pelajar.

Partanto, Pius A, \& M. Dahlan al-Barry, Kamus Ilmiah Populer (Surabaya: Arkola, 1994).

Sabda, Syaifuddin, Model Kurikulum Terpadu IPTEK \& IMTAQ, Jakarta: PT. Ciputat Press Group, 2006.

S. Hall, Calvin. \& Gardner Lindzey. 1993. Teori-Teori Psikodinamik (Klinis). Yogyakarta: Kanisius.

Shaleh, Abdul Rachman, Madrasah dan Pendidikan Anak Bangsa (Jakarta: RajaGrafindo Persada, 2004).

SM, Ismail dkk, Dinamika Pesantren dan Madrasah, Yogyakarta: Pustaka Pelajar, 2002

Sukanto, Sujono. 1986. Pengantar Penelitian Hukum. Cet. III. Jakarta, UII Press.

Trianto. 2007. Model Pembelajaran Terpadu, Teori dan Praktek. Jakarta: Prestasi Pustaka.

Wiryokusumo, Iskandar. dan Usman Mulyadi, 1988. Dasar-Dasar Pengembangan Kurikulum, Jakarta: Bima Aksara.

Yunus, Mahmud. At-Tarbiyyah wa At-Ta'lim. t.t. 